\title{
ARTICLE
}

\section{Natural gold particles in Eucalyptus leaves and their relevance to exploration for buried gold deposits}

Melvyn Lintern', Ravi Anand ${ }^{1}$, Chris Ryan ${ }^{2} \&$ David Paterson ${ }^{3}$

Eucalyptus trees may translocate Au from mineral deposits and support the use of vegetation (biogeochemical) sampling in mineral exploration, particularly where thick sediments dominate. However, biogeochemistry has not been routinely adopted partly because biotic mechanisms of Au migration are poorly understood. For example, although Au has been previously measured in plant samples, there has been doubt as to whether it was truly absorbed rather than merely adsorbed on the plant surface as aeolian contamination. Here we show the first evidence of particulate Au within natural specimens of living biological tissue (not from laboratory experimentation). This observation conclusively demonstrates active biogeochemical adsorption of $\mathrm{Au}$ and provides insight into its behaviour in natural samples. The confirmation of biogeochemical adsorption of $\mathrm{Au}$, and of a link with abiotic processes, promotes confidence in an emerging technique that may lead to future exploration success and maintain continuity of supply.

\footnotetext{
${ }^{1}$ CSIRO Earth Science and Resource Engineering, 26 Dick Perry Avenue, Kensington, Western Australia 6152, Australia. ${ }^{2}$ School of Physics, University of Melbourne, Melbourne, Victoria 3010, Australia. ${ }^{3}$ Australian Synchrotron, 800 Blackburn Road, Clayton, Victoria 3168, Australia. Correspondence and requests for materials should be addressed to M.L. (email: mel.lintern@csiro.au).
} 
$\mathrm{M}$ ineral explorers need to find new ore deposits. New $\mathrm{Au}$ discoveries are down by $45 \%$ over the last 10 years ${ }^{1}$. Novel exploration techniques are required to find the more difficult deposits hidden beneath sediments ${ }^{2}$. Furthermore, these new techniques need to be underpinned by an improved understanding of mechanisms of metal mobilization that are currently poorly understood ${ }^{3}$. Biogeochemistry for mineral exploration is one such relatively new technique, but defining the boundaries as to when and where it may or may not be effective has been difficult ${ }^{4}$. One of the major technical problems facing research involving natural samples is that $\mathrm{Au}$ concentrations in vegetation are commonly very low $(<1-2 \text { p.p.b. })^{5,6}$. There is no unequivocal evidence that $\mathrm{Au}$ is actually absorbed by plants over mineral deposits and that currently measured $\mathrm{Au}$ is not merely a result of dust contamination of samples ${ }^{7,8}$. Thus explorers are reticent to embrace an important emerging technique in which they lack confidence in its applicability, data quality and interpretation of results.

The Freddo Gold Prospect is an ideal location to investigate potential mechanisms for the chemical transport of $\mathrm{Au}$. It is located $40 \mathrm{~km}$ north of Kalgoorlie (Western Australia) in the Yilgarn Craton and lies beneath a gently sloped drainage catchment with no known sources of surface contamination: It is undisturbed by mining activity, there is no outcropping mineral deposit and the $\mathrm{Au}$ itself is concealed by $\sim 30 \mathrm{~m}$ of barren, Cainozoic alluvial and colluvial deposits infilling a palaeovalley (Fig. 1) $)^{9}$. The mineral deposit at Freddo is a subeconomic supergene type measuring $100 \mathrm{~m}$ by $200 \mathrm{~m}$ at $35 \mathrm{~m}$ depth, discovered by exploratory drilling. The simplified regolith profile at Freddo consists (from top to bottom) of a red calcareous kaolinitic clay soil ( $2 \mathrm{~m}$ thick), grading to a mottled red and pale grey kaolinitic clay $(12 \mathrm{~m})$, grey smectitic clay $(10 \mathrm{~m})$, quartzose fluvial sand $(8 \mathrm{~m})$ overlying a saprolite of greenish brown smectitic clay containing Au (Fig. 2). Fresh rock occurs at about $40 \mathrm{~m}$ depth. Large Eucalyptus trees (some $>10 \mathrm{~m}$ in height) grow over the deposit in an open woodland setting and make it an ideal study site to examine the uptake of Au.

At Barns Gold Prospect $(25 \mathrm{~km}$ north of Wudinna, South Australia), previous studies have shown that vegetation samples, soil and calcrete have anomalously high $\mathrm{Au}$ contents ${ }^{10}$. Like Freddo, Barns is an undisturbed site well-suited to $\mathrm{Au}$ mobilization studies. The Barns Au deposit lies within Archean rocks of the Gawler Craton that have been weathered to $50 \mathrm{~m}$ depth $^{11}$. The Barns regolith consists of saprolite overlain by up to $8 \mathrm{~m}$ high aeolian sand dunes that have developed over the last 20,000 years ${ }^{10}$. Gold is patchily distributed in the saprolite and there is a sub-economic Au supergene deposit ( $500 \mathrm{~m}$ by $200 \mathrm{~m}$ ) $35 \mathrm{~m}$ below the dune. Calcrete within the top $2 \mathrm{~m}$ of the saprolite beneath the dune contains anomalous $\mathrm{Au}$ concentrations (35 p.p.b.) against a background of $<1$ p.p.b. Younger calcrete, intimately associated with plant roots (rhizoliths), occurs within the sand dune, and has an anomalous $\mathrm{Au}$ content (up to 9 p.p.b. $)^{10}$. Small Eucalyptus trees (mostly $<5 \mathrm{~m}$ in height) grow in the sand dunes over the deposit.

The precipitation of nanoparticulate $\mathrm{Au}$ from laboratory studies, using a variety of biological, physiological and chemical procedures, are widely reported in the literature ${ }^{12}$ and nanoparticulate $\mathrm{Au}$ has been documented in inorganic environments ${ }^{13}$. Greenhouse and laboratory experiments utilizing the uptake of Au by plants for nanoparticle production are frequently undertaken. These experiments typically use concentrations of $\mathrm{Au}$ much higher than that is found in the natural environment. However, there have been few reported greenhouse experiments undertaken to investigate Au uptake of plants commonly used in mineral exploration. Plants that have a natural barrier to $\mathrm{Au}$ uptake would negate their use in biogeochemical exploration ${ }^{4}$ as the Au concentration in a plant would be unrelated to the Au concentration in the regolith in which it was growing.

Here, native Australian Eucalyptus and Acacia seedlings were grown experimentally under greenhouse conditions in sand pots dosed with $\mathrm{Au}$ to investigate the location and nature of nanoparticles. We collect samples from two field sites (Freddo and Barns), conduct greenhouse experiments and complex analytical procedures to investigate the nature of $\mathrm{Au}$ variability and biotic-abiotic-linked mechanisms for Au mobilization and precipitation. A Eucalyptus tree investigated over the deeply buried $\mathrm{Au}$ deposit at Freddo has Au particles forming in its foliage with similar features to those grown in our laboratory experiments, whereas leaves at Barns demonstrate the release of Au-containing exudates. Collectively, these results are important for mineral explorers to consider as they access more difficult terrains with deeper sediments and assess more subtle surficial geochemical anomalies.

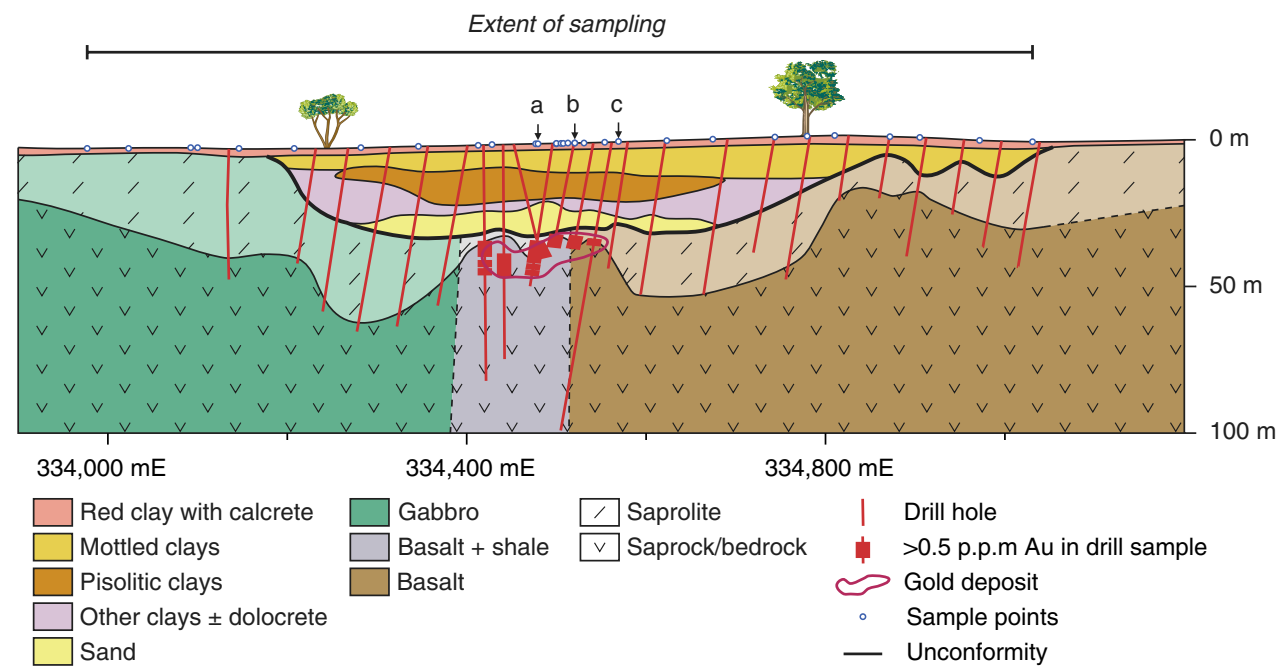

Figure 1 | Location of the sampling traverse at Freddo Au deposit. The underlying regolith stratigraphy and Au deposit is shown. The sampling traverse (1.3 km in length) is orientated perpendicular to the palaeochannel. Detailed sampling was undertaken at sites RD 50 (a), RD 56 (b) and RD 68 (c). 


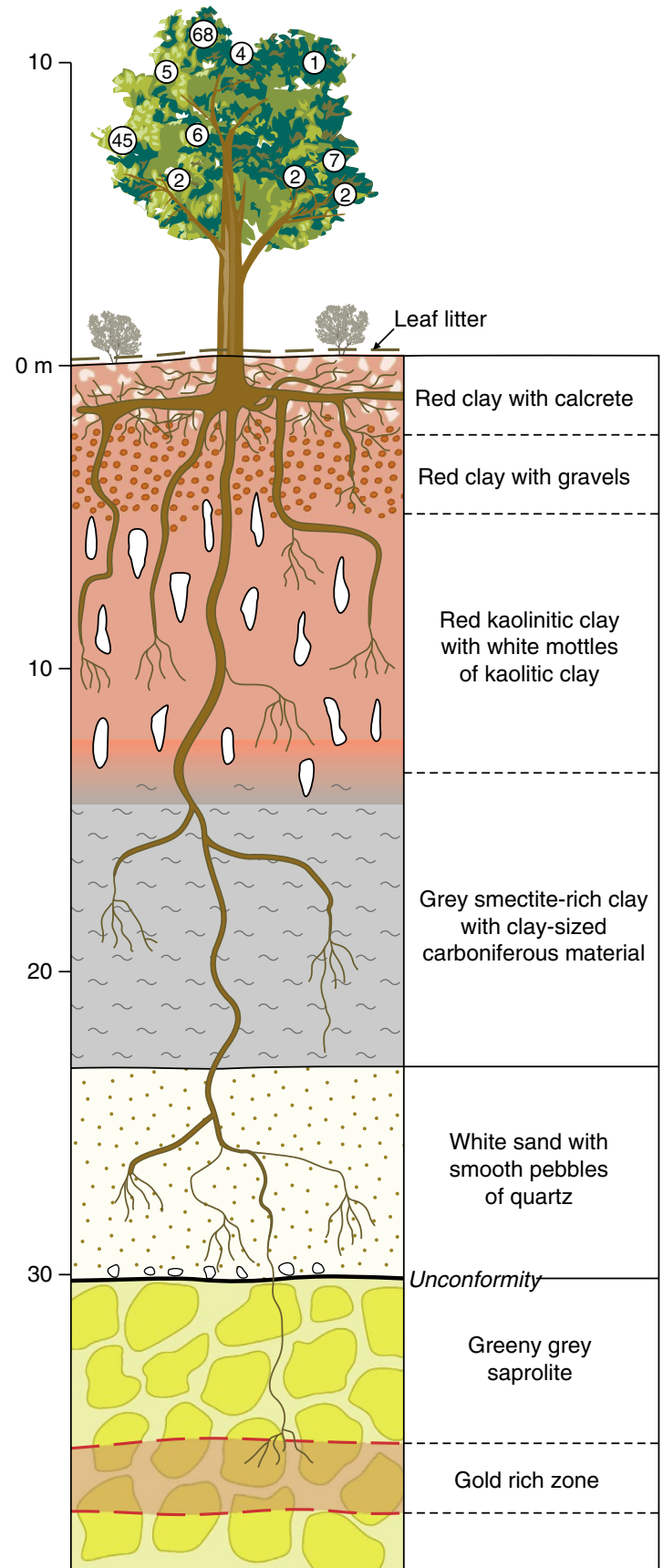

Figure 2 | Eucalyptus root system through regolith at Freddo Au

prospect. The relationship between the Eucalyptus root system, regolith stratigraphy and location of the Freddo Au deposit is shown. Circled numerical data in foliage corresponds to typical sample location and bulk Au analyses of leaves (see Supplementary Fig. S1 and Supplementary Table S2 for samples RD50T1-1-10). Note the unconformity (marked by presence of rounded river pebbles) at $30 \mathrm{~m}$ depth beneath which is the weathered bedrock containing the Au deposit.

\section{Results}

Freddo. Samples from the large ( $>10 \mathrm{~m}$ tall) Eucalyptus trees at Freddo were found to be highly anomalous in Au exclusively and directly over the buried deposit (Fig. 3, Supplementary Table S1). The maximum Au concentrations in dried leaves, twigs, bark, litter and soil were 80, 44, 4, 12 and 41 p.p.b., respectively, with background concentrations of 0.1 p.p.b. for plant material, 1 p.p.b. for litter and 6p.p.b. for soil. Thus some tree parts (leaves and twigs) were richer in $\mathrm{Au}$ than others (bark). Tree trunk (heartwood and sapwood) samples contained between 0.1 and 0.7 p.p.b. $\mathrm{Au}$. Owing to its large mass, the tree trunk represents a major storage organ for Au.

In order to investigate the possibility of particulate $\mathrm{Au}$ in the Eucalyptus foliage, a three-stage sequential experimental procedure was adopted. First, ten foliage samples, consisting of leaves and twigs, were each collected from around the canopies of two trees, one over the deposit (RD50) and one over background, $200 \mathrm{~m}$ distant (RD68) (see Fig. 3 for location). Leaves (100 g subsamples), separated from each of the ten foliage samples over the deposit, were analysed and had highly variable $\mathrm{Au}$ contents ranging from 1 to 68 p.p.b. (RD50) and 1 to 16 p.p.b. in background sample RD68 (Supplementary Fig. S1 and Supplementary Table S2). Second, variable Au concentrations (5-359 p.p.b., mean 46 p.p.b. and standard deviation 64 p.p.b.) were noted again when 20 individual leaves were randomly selected from bulk sample RD56 (see Fig. 3 for location), divided into three leaf parts $(n=60)$ and separately analysed (Supplementary Fig. S2 and Supplementary Table S3). Third, a further 20 leaves were randomly selected from bulk sample RD56. Sixty leaf discs (diameter of $6 \mathrm{~mm}$ ) were punched out from the 20 leaves and analysed using the synchrotron X-ray Fluorescence Microprobe (XFM) equipped with a Maia detector $^{14}$ to maximize the probability of finding $\mathrm{Au}$ particles and to map the distribution of other elements (Supplementary Figs S3 and S4). High-resolution $(1 \mu \mathrm{m})$ mapping of the discs identified several $\mathrm{Au}$ particles up to $8 \mu \mathrm{m}$ in length indicating that $\mathrm{Au}$ had precipitated naturally within the leaves (Fig. 4a,b). The XFMMaia combination is particularly well-suited to penetrate organic matrices non-destructively, speedily map large areas at high resolution and detect small $(1-10 \mu \mathrm{m})$ discrete heavy metal particles, for example, Au located within the matrix ${ }^{15}$. Some $\mathrm{Au}$ particles were associated with Ca oxalate crystals (Fig. 4b). This is the first time, to our knowledge, that naturally occurring (nonlaboratory generated) Au particles have been imaged within the cells of biological tissue. Gold particles have been imaged adsorbed on the surface of tree bark but these probably have an aeolian origin ${ }^{4}$.

Samples taken from a soil profile near Freddo exemplify the strong relationship between $\mathrm{Au}$ and calcrete commonly found in southern Australia (Fig. 5) ${ }^{10}$. Gold concentrations in the soil profile have a maximum of 177 p.p.b. and correspond to a concentration of $7.1 \% \mathrm{Ca}$ (as calcite). The strong association between $\mathrm{Ca}$ and $\mathrm{Au}$ in the profile indicates that the physicochemistry of these elements is controlled by a similar mechanism; where the Ca occurs as gypsum (Fig. 5; Supplementary Table S4), the $\mathrm{Au}-\mathrm{Ca}$ relationship is weaker.

Barns exudates. Exudate samples collected from vegetation over the Barns deposit had 20 times more $\mathrm{Au}$ (maximum of $0.004 \mu \mathrm{g}$ ) than the background samples $800 \mathrm{~m}$ distant $(0.0002 \mu \mathrm{g}$; Supplementary Fig. S5 and Supplementary Table S5). This indicates that Eucalyptus trees, in addition to compartmentalizing Au in $\mathrm{Ca}$ oxalate crystals (as found for the Freddo samples), expel soluble $\mathrm{Au}$ through their leaves. As exudates evaporate from the leaf surface $\mathrm{Au}$ salts are precipitated which, under normal circumstances, would be dislodged by wind or dissolved by rain and transferred to soil.

Greenhouse study. In a separate, related laboratory experiment, Eucalyptus and Acacia seedlings were grown experimentally under greenhouse conditions in sand pots and dosed with 1,000 p.p.m. Au. Scanning electron microscopy (SEM) (equipped 


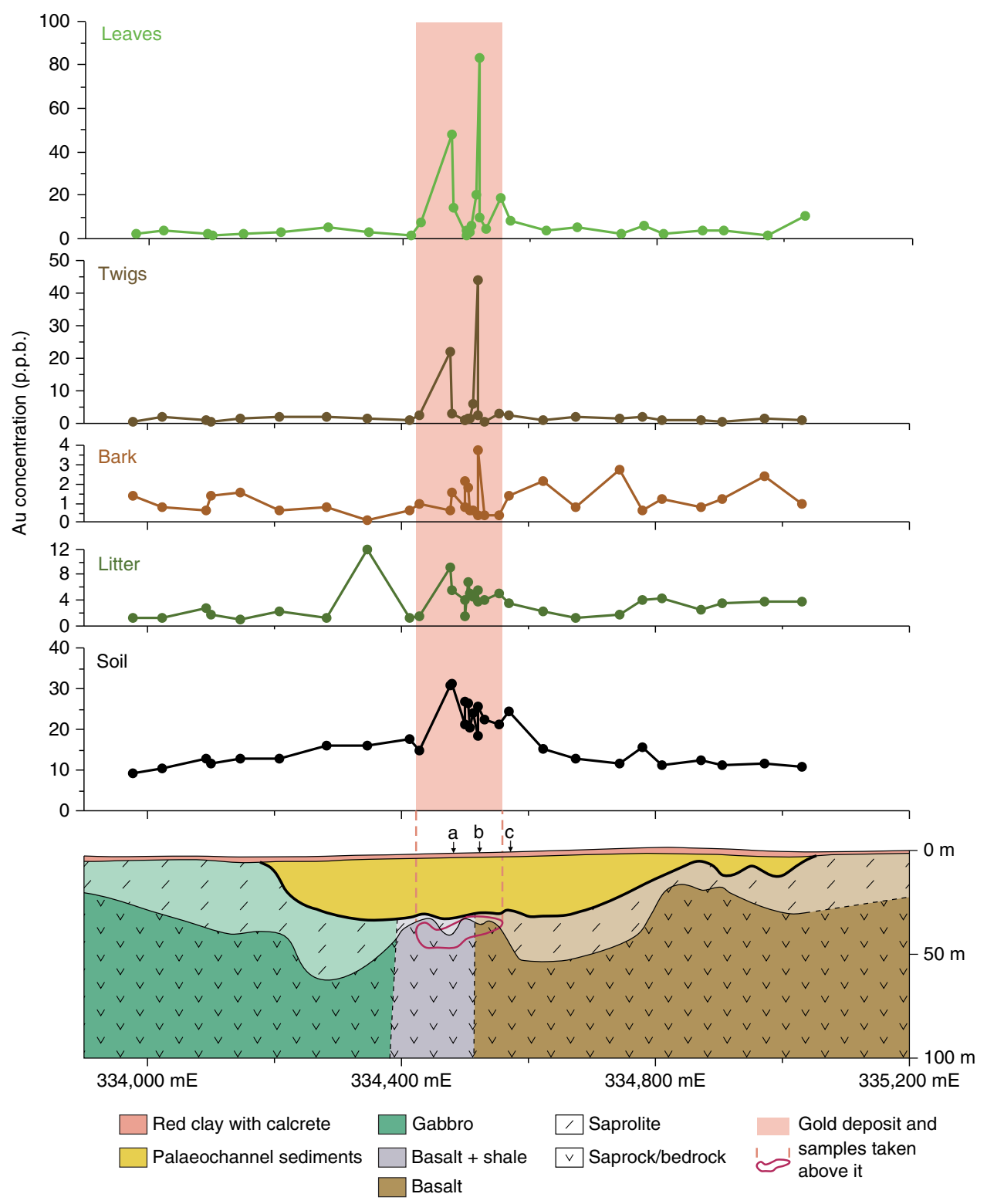

Figure 3 | Gold concentrations from sampling traverse at Freddo Au deposit. Data shows Au concentrations in parts per billion contained within a variety of sample media. A variety of sample media were tested for Au including bark, leaves, twigs and soil. Note how the concentrations of Au are highest in the leaves, twigs and soil sample media directly over the buried Au deposit (those highlighted in pink shading); litter and bark were not anomalous in Au. At sites RD 50 (a) and RD 68 (c), ten samples of foliage were taken from around the tree to examine the variability of Au in leaves (see Supplementary Table S2). At site RD 56 (b), 20 leaves were taken from the reference bulk sample and Au variability was investigated in detail (see Supplementary Table S3).

with an energy-dispersive spectrometer (EDS)) analyses of the leaves showed that they contained Au particles with some partly coating $\mathrm{Ca}$ oxalate crystals in a similar manner to our observations in the natural samples (Fig. $4 \mathrm{c}-\mathrm{g}$ ).

\section{Discussion}

The demonstration of absorbed $\mathrm{Au}$ in vegetation in Eucalyptus foliage from Freddo and Barns is a crucial result in our understanding of $\mathrm{Au}$ mobilization. Identification of such naturally low concentrations of $\mathrm{Au}$ has not been attempted before but by carefully selecting samples (using the sequential procedure) with the highest concentration and using XFM-Maia, we maximized the probability of being able to achieve the observations. The larger natural Au particles appear to occur in an irregular shape similar to experimentally produced $\mathrm{Au}$ and, furthermore, the association of Au with Ca oxalate crystals was similar for natural and artificially produced specimens. Although $\mathrm{Ca}$ oxalate is principally involved with the regulation of $\mathrm{Ca}$ in the plant ${ }^{16}$, it has been implicated in toxic metal compartmentalization ${ }^{17}$. Gold is probably toxic to plants and is moved to its extremities ${ }^{18}$ (such as leaves) or in preferential zones ${ }^{19}$ within cells in order to reduce deleterious biochemical reactions. Gold toxicity is not confined to plants: recently, a biochemical mechanism for extracellular precipitation of Au by a bacterium was described ${ }^{20,21}$.

The findings from these field sites and laboratory experiments enable us to propose a tentative model for Au mobilization and precipitation for this biotic-abiotic system. We assert that climatic and biological factors at Freddo, Barns and elsewhere 

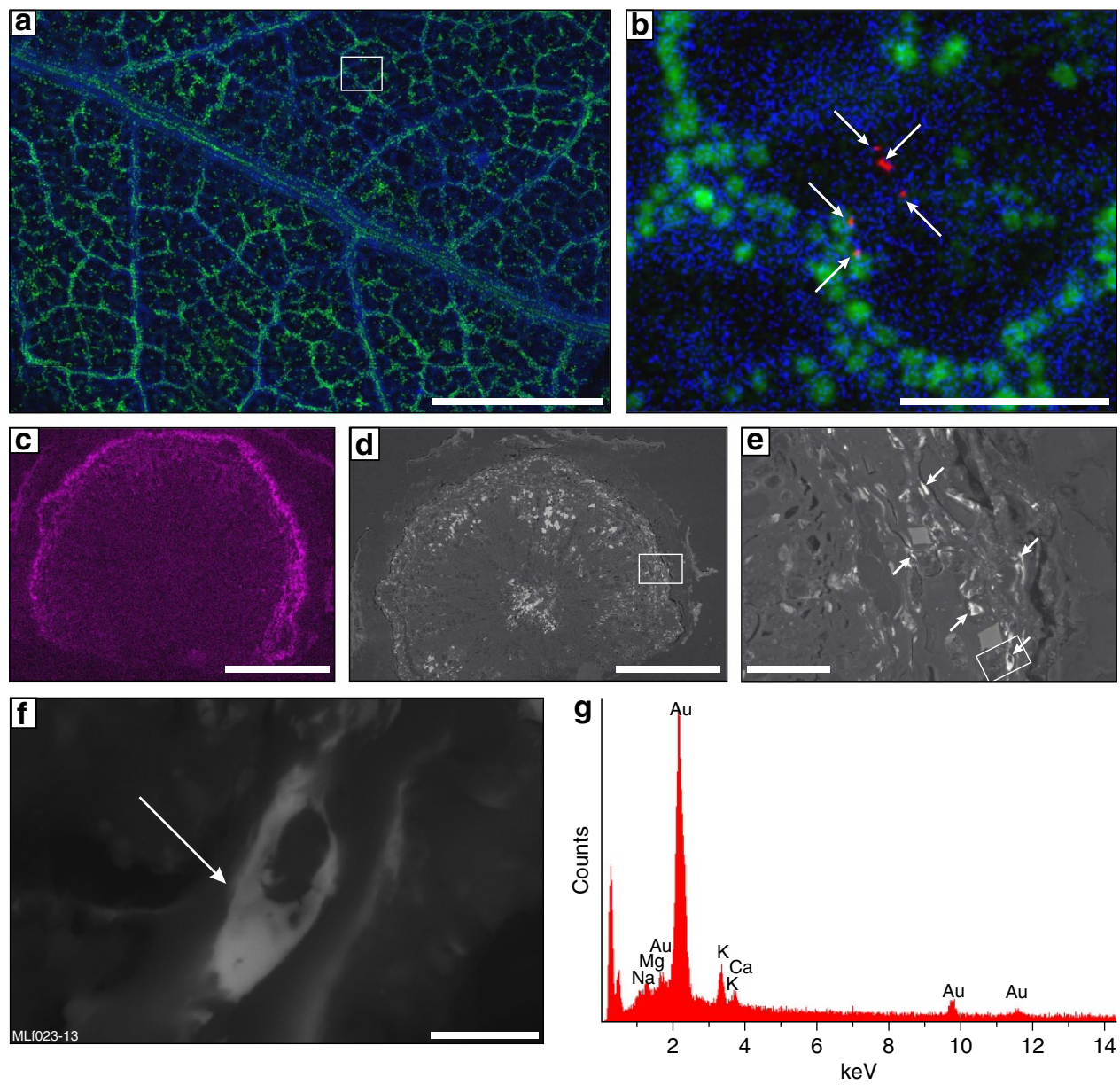

Figure 4 | Particulate Au and analytical data from laboratory-grown and natural specimens. (a) Synchrotron image showing distribution of Cu (blue), $\mathrm{Sr}$ (oxalate crystals, green) and Au (red) in natural leaf specimen. Strontium is a proxy for Ca; boxed area in a is shown in $\mathbf{b}$. (b) Detailed view showing isolated particulate Au grains (red, arrowed) and two of which are attached to the surface of Ca oxalate crystals (green). (c) SEM-EDS map of twig section showing examples of Au (purple) in laboratory-grown plants. (d) SEM BSE image of laboratory-grown plants in c showing plant structure with brighter areas showing Au; boxed area in (d) is shown in e. (e) Detailed BSE view showing distribution of Au (bright areas). Arrows point at some examples of Au (including those particles attached to Ca oxalate crystals); boxed area in (e) is shown in $\mathbf{f}$. (f) Detailed BSE view showing Au particle $8 \mu \mathrm{m}$ in length. (g) Spectra showing identification of Au by SEM-EDS. Scale bars in $\mathbf{a}, \mathbf{c}$, $\mathbf{d}$ and $\mathbf{b}$, e and $\mathbf{f}$ indicate scale as 500,50 and $5 \mu \mathrm{m}$, respectively.

are crucial for the transportation of Au to the surface from great depth. The Eucalyptus trees are part of woodland at Freddo and at Barns stretching over several thousand square kilometres. Both prospects are in semi-arid climates with annual average rainfall of $260-290 \mathrm{~mm}$, evapotranspiration rates in excess of $2,600 \mathrm{~mm}$ per annum and average maximum January temperatures of $34^{\circ} \mathrm{C}$. Despite these harsh climatic conditions, it is significant that the large trees at Freddo, in particular, are able to thrive. The Eucalyptus root system is unusually deep and extensive ${ }^{22}$ with sinker roots in one species (Eucalyptus marginata) documented at $40 \mathrm{~m}$ depth $^{23}$ (Fig. 2) which, along with other physiological and anatomical adaptations, enables some species to flourish in an arid environment and be drought tolerant. For example, Eucalyptus species commonly have small, tough, vertically hanging leathery leaves comprised of hard sclerochyma tissue enabling them to resist wilting ${ }^{24}$.

The link between abiotic and biotic geochemical processes at the earth surface is becoming demonstrably and irresistibly stronger. Our combined data indicate that there is a significant but irregularly distributed mass of Au within the tree derived from $35 \mathrm{~m}$ below the surface, which is released and accumulates in the soil after leaf fall and when the tree dies. Calcrete (pedogenic carbonate or caliche) is a common component of the soil in southern Australia and provides an inorganic testimony for this organic activity ${ }^{25}$. The phenomenon of Au accumulating in calcrete has been well documented, primarily in Australia ${ }^{10,26,27}$. Calcrete and Eucalyptus woodland growing in semi-arid areas of southern Australia are commonly associated ${ }^{28}$ Samples taken from the soil profile near Freddo illustrate the typical strong relationship between Au and calcrete in Eucalyptus woodland found elsewhere (Fig. 5). The correlation between these two fundamentally different elements $(\mathrm{Ca}$ and $\mathrm{Au})$ in calcrete is due to their similar physical response to rainfall and evapotranspiration (rather than a chemical response) averaged over thousands of years ${ }^{10}$. Calcrete is an evapotranspiration product, in part, of the trees rather than a specific adaptation by the trees to grow in alkaline soils ${ }^{29}$ and is commonly intimately associated with plant roots, for example, as calcareous rhizolith ${ }^{30}$. Calcrete's calcite principally originates from inputs of meteoric ( $\mathrm{Ca}$, marine $\left.{ }^{31}\right)$ and respiration $\left(\mathrm{CO}_{2}\right.$, microbes and plant roots $\left.{ }^{32}\right)$ origins. Soil moisture is required for $\mathrm{Au}$ and $\mathrm{Ca}$ to be mobilized and water-soluble (ionic) Au itself is nearly twice as high in calcrete (15\%) compared with other near-surface regolith materials (8\% (ref. 33)). The Au association with calcrete has been widely exploited by the mineral exploration industry and many operating mines and prospects owe their existence 


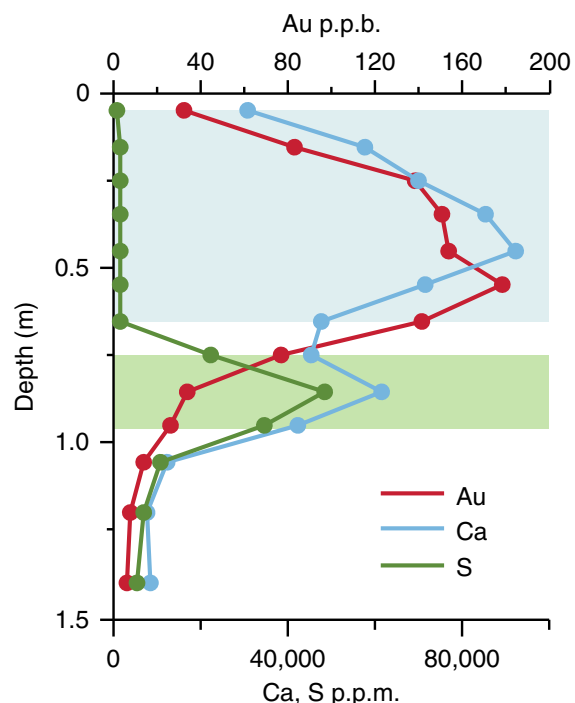

Figure 5 | Relationship between key elements in a calcareous soil profile near Freddo. The strong relationship between $\mathrm{Au}$ and $\mathrm{Ca}$ in the upper part of the profile (shaded blue, related to calcite) is common in Australian soils situated near Au deposits. The relationship between $\mathrm{Au}$ and $\mathrm{Ca}$ is weaker in the lower part of the profile as some of the $\mathrm{Ca}$ (with $\mathrm{S}$ ) is in gypsum (shaded green) which is not associated with Au.

to exploration targeting the $\mathrm{Au}$ in calcrete correlation ${ }^{34}$. Interestingly, most of these have been in Australia.

Our preliminary model for the biomediated formation of abiotic and biotic $\mathrm{Au}$ anomalies in Eucalyptus woodland is tempered by climatic processes. Gold at the woodland surface (in plants and soil) is supplemented through deep-rooted trees that absorb and transport Au from the buried deposit. It is translocated to the trees from the deposit during times of high water demand when sinker roots access deeper regolith moisture ${ }^{22}$. Then, ionic $\mathrm{Au}$ is transported in water through the vascular system of the trees at sub-toxic concentrations then reduced (to $\mathrm{Au}^{0}$ ) and precipitated within the cells of the tree. Gold occurs throughout the trees but the highest concentrations are found in the foliage where hydrostatic pressures fluctuate greatly. Gold crystals may grow as a result of the propensity of ionic Au to reduce and autocatalytically precipitate ${ }^{35}$. Gold is released from trees through leaf fall, leaf exudates, bark shedding, limb/branch loss and plant death and is transferred to soil. It may be dissolved in the soil and adsorbed through the lateral roots of understorey plants and trees. Plant debris (from trees and shrubs) contributes to degrading organic matter and creates subtle $\mathrm{Au}$ anomalies in the soil. Finally, $\mathrm{Au}$ is transported laterally and vertically in the soil (including those dominated by calcrete) through processes of physical erosion (litter and soil) and chemical dispersion ${ }^{36}$. Gold (and calcite) is precipitated with calcrete when moisture is removed by evapotranspiration but some is re-absorbed and precipitated in the plants. Micro-organisms ${ }^{37}$ and fungi ${ }^{38}$ are implicated in the mobilization and intra- and extra-cellular precipitation of $\mathrm{Au}$ in the rhizosphere. A dynamic equilibrium in the Au flux occurs for the soil-vegetation-deposit system although absolute concentrations in soil and plants are determined by other factors. For example, random dispersive environmental events such as wildfire, flood and strong winds serve to lower the flux so that $\mathrm{Au}$ brought to the surface by deep-rooted trees will no longer be able to sustain the soil Au concentrations at a sufficient rate to counteract erosional losses.

We have considered alternative mechanisms of $\mathrm{Au}$ transport operating at depth, beneath cover but have found these to be unconvincing in these settings ${ }^{2}$. For example, the water tables at our study sites occur at about $30 \mathrm{~m}$ which reduces the possibility of transport of $\mathrm{Au}$ nanoparticles via gas bubbles ${ }^{39}$. The deposits are located within the tectonically stable Archean cratons and the paucity of recent tectonic activity to create faults suggests that seismic pumping of groundwater or barometric pumping of gases is unlikely to bring Au up to the trees ${ }^{40}$. Hydraulic lift by deeprooted vegetation is a compelling mechanism of transport ${ }^{41}$. It not only provides an explanation for the Au adsorbed by the trees but also the existence of the $\mathrm{Au}$ in calcrete anomaly beneath them.

Despite the decline in discoveries ${ }^{1}$, falling ore grades and increasing demand for $\mathrm{Au}^{42}$, new exploration technologies for $\mathrm{Au}$ deposits, incorporating the deep penetrating ability of certain trees, have been seldom reported ${ }^{43}$. Analytical problems, extremely low concentrations and variable data in comparison with traditional soil sampling have held back the use of vegetation for $\mathrm{Au}$ exploration ${ }^{4}$. Our results add to the mounting evidence that demonstrate enrichment of $\mathrm{Au}$ in biota and soils are inextricably linked and that disparity between biotic and abiotic processes at the Earth's surface is, at best, indistinct ${ }^{44}$. Mineral exploration will benefit by embracing and understanding mechanisms of the biota-mineral-climate continuum and will be important in finding new $\mathrm{Au}$ deposits undercover into the future.

\section{Methods}

General field sampling. Soil samples (about $1 \mathrm{~kg}$ ) were collected with a plastic trowel within $1 \mathrm{~m}$ of the base of the tree trunks and put into plastic bags. Sampling depth was from $0-10 \mathrm{~cm}$. Bark samples (about $300 \mathrm{~g}$ ) were collected from base of the tree trunk and placed into calico bags. Litter samples (about $300 \mathrm{~g}$ ) were collected into calico bags from above where the soil sample was taken. Foliage (collected as branches, $2 \mathrm{~kg}$ ) was removed from trees using Teflon-coated secateurs and a truck mounted cherry picker (or basket crane) at Freddo or from ground level at Barns. The leaves and twigs were separated from the main branches with Teflon-coated secateurs and placed into calico bags. All samples were collected during one campaign.

Soil profile. A soil profile was excavated using a back hoe excavator. The face of the soil profile was cleaned down with a brush and samples taken using a plastic trowel approximately every $0.1 \mathrm{~m}$.

Leaf exudates. Dissolved leaf exudates were sampled and analysed from the foliage of Eucalyptus trees growing on the dunes using transpiration collectors (Supplementary Fig. S6). Large plastic (transpiration) bags $(1.2 \mathrm{~m}$ by $0.5 \mathrm{~m}$ ) were placed around branches containing foliage (leaves and twigs). The opening of each bag was tied around the branches, supporting the foliage, using a plastic cable tie. A corner of the bag was tied to the trunk in such a way as to allow exudates to drain freely from the foliage into the bag. Bags were left tied around branches overnight for approximately $15 \mathrm{~h}$ after which time the plastic bag corner was cut and the exudates drained into a screw-capped plastic sample container. These were directly analysed by inductively coupled mass spectrometry (ICP-MS).

Sample preparation. For the foliage, leaves were separated from the branches in the laboratory to make the twig and leaf samples. The leaves, twigs, bark and litter were milled with a cross beater mill to a fine powder. Soil samples were sieved through a $250 \mu \mathrm{m}$ plastic sieve and the sample milled to a nominal $<75 \mu \mathrm{m}$ particle size in a ring mill.

General sample analyses. About $10 \mathrm{~g}$ of organic-rich sample (that is, bark, litter, twigs and leaves) was submitted for analysis. Standards and duplicates analysed at the same time were in good agreement (errors $<10 \%$ ). About $4 \mathrm{~g}$ of material was digested with $10 \mathrm{ml}$ of nitric acid overnight and then a further $10 \mathrm{ml}$ of nitric and hydrochloric acids were added and digested for $2 \mathrm{~h}$ at $90^{\circ} \mathrm{C}$. The digest was diluted to a set volume and analysed by ICP-MS.

For soil, about $25 \mathrm{~g}$ of sample was digested by aqua regia and analysed by ICPMS. The X-ray diffraction was done using an Endeavour D4 (Bruker Corporation).

The leaf parts (samples RD56T1-20 left, middle and right) were digested without milling using the procedure described above for organic samples and with smaller solution volumes to keep concentrations higher. The weight of individual leaf parts was recorded to calculate final concentration as dry weight. 
Greenhouse study. Seeds of Eucalyptus salmonophloia and Acacia aneura were grown in $150 \times 40 \times 40 \mathrm{~mm}$ pots containing acid-washed beach sand and pelleted slow-release nutrient. The seedlings underwent four treatments $(25$ seedlings for each treatment) of Au solution: 0, 10, 100 and 1,000 p.p.b. Au. Gold was added daily $(10 \mathrm{ml})$ in solution as a cyanide complex $(\mathrm{KAuCN})$ dissolved in deionised water using a pipette. The experiment continued for 3 months. At the completion of this treatment one each of the Eucalyptus and Acacia plants of the grown plants from the 1,000 p.p.b. Au treatment had $10 \mathrm{ml}$ of 1,000 p.p.m. Au added to them. Samples of these organic materials were mounted in epoxy resin and polished exposing the plant tissue ready for SEM analyses.

Synchrotron analyses. Leaf discs were punched out from the Freddo leaves using a $6 \mathrm{~mm}$ diameter tungsten steel hole punch. Three discs were punched from each of 20 leaves at random to make 60 samples. These were mounted directly on a Perspex holder using Mylar tape that was fixed, (in turn) in front of the beam source using locating magnets. The X-ray fluorescence analyses were performed with a Maia 384 detector array ${ }^{45}$ at the Australian Synchrotron facility and X-rays focussed into a beam spot of $\sim 1.5 \mu \mathrm{m}$, dwell of $\sim 1-2 \mathrm{~ms}$ per pixel, energy of $16.5 \mathrm{KeV}$ using the Kirkpatrick-Baez-mirror-based lens system on the X-ray Fluorescence Microprobe (XFM) beamline ${ }^{15}$. Platinum, Mn, Ni and Fe foils were used to calibrate the beam. This system enables rapid analysis $(8 \mathrm{~h})$ of a large area $\left(\sim 2 \mathrm{~cm}^{2}\right)$ at about $1-2 \mu \mathrm{m}$ spatial resolution; this is at least an order of magnitude more efficient compared with conventional X-ray detectors to identify Au in soil samples.

SEM analyses. The SEM imaging and analyses were performed using a backscattered electron (BSE) detector on a Philips XL40 controlled pressure SEM fitted with an energy-dispersive X-ray analysis EDS.

\section{References}

1. Chan, K. New gold discoveries decline by $45 \%$ http://intierrarmg.com/Libraries/ Brochures_and_Flyers/New_gold_discoveries_decline_45_-_25_March_2013. sflb.ashx (2013).

2. Cameron, E. M. et al. Finding deeply buried deposits using geochemistry. Geochem: Explor. Env. Anal. 4, 7-32 (2003).

3. Aspandiar, M. F. et al. Mechanisms of metal transfer through transported overburden within the Australian regolith. Explore -News. Assoc. App. Geochem. 125, 9-12 (2004).

4. Dunn, C. E. Biogeochemistry in Mineral Exploration Vol. 9 (ed. Hale, M.) 1-450 (Elsevier, 2007).

5. Erdman, J. A. \& Olson, J. C. The use of plants in prospecting for gold: a brief overview with a selected bibliography and topic index. J. Geochem. Explor. 24, 281-309 (1985).

6. Eisler, R. Gold concentrations in abiotic materials, plants, and animals: a synoptic review. Environ. Monit. Assess. 90, 73-88 (2004).

7. Dunn, C. Mineral exploration beneath temperate forests: the information supplied by trees. Exploration Mining J. 4, 197-204 (1995).

8. Arne, D. C., Stott, J. E. \& Waldron, H. M. Biogeochemistry of the Ballarat East Goldfield, Victoria, Australia. J. Geochem. Explor. 67, 1-14 (1999).

9. Kern, A. M. \& Commander, P. Cainozoic stratigraphy in the Roe Palaeodrainage of the Kalgoorlie region, Western Australia. Geol. Surv. W. Aust. Rep. 34, 85-95 (1993).

10. Lintern, M. J. Vegetation controls on the formation of gold anomalies in calcrete and other materials at the Barns Gold Prospect, Eyre Peninsula, South Australia. Geochem.-Exploration Environ. Anal. 7, 249-266 (2007).

11. Drown, C. G. The Barns Gold Project-discovery in an emerging district. Mines Energy Res. S. Aust. Quart. J. 28, 4-9 (2003).

12. Panda, T. \& Deepa, K. Biosynthesis of gold nanoparticles. J. Nanosci. Nanotech. 11, 10279-10294 (2011).

13. Hough, R. M., Noble, R. R. P. \& Reich, M. Natural gold nanoparticles. Ore Geol. Rev. 42, 55-61 (2011).

14. Ryan, C. G. et al. Elemental X-ray imaging using the Maia detector array: the benefits and challenges of large solid-angle. Nucl. Instrum. Methods A 619, 37-43 (2010).

15. Paterson, D. et al. The X-ray fluorescence microscopy beamline at the Australian synchrotron. AIP Conf. Proc. 1365, 219-222 (2011).

16. Franceschi, V. R. \& Nakata, P. A. Calcium oxalate in plants: formation and function. Annu. Rev. Plant Biol. 56, 41-71 (2005).

17. Mazen, A. M. A. \& El Maghraby, O. M. O. Accumulation of cadmium, lead and strontium, and a role of calcium oxalate in water hyacinth tolerance. Biol. Plantarum 40, 411-417 (1998).

18. Girling, C. A. \& Peterson, P. J. Gold in plants. Gold Bull. 13, 151-157 (1980).

19. Gardea-Torresdey, J. L. et al. Formation and growth of au nanoparticles inside live alfalfa plants. Nano. Lett. 2, 397-401 (2002).

20. Johnston, C. W. et al. Gold biomineralization by a metallophore from a goldassociated microbe. Nat. Chem. Biol. 9, 241-243 (2013).

21. Soenen, S. J. et al. Cytotoxic effects of gold nanoparticles: a multiparametric study. Acs Nano 6, 5767-5783 (2012).
22. Kimber, P. C. The root system of jarrah (Eucalyptus marginata). Forest Dept W. Aust. Res. Pap. 10, 1-6 (1974).

23. Dell, B., Bartle, J. R. \& Tacey, W. H. Root occupation and root channels of jarrah forest subsoils. Aust. J. Bot. 31, 615-627 (1983).

24. James, S. A. \& Bell, D. T. Morphology and anatomy of leaves of Eucalyptus camaldulensis clones: variation between geographically separated locations. Aust. J. Bot. 43, 415-433 (1995).

25. Northcote, K. H. et al. A Description of Australian Soils 1-170 (CSIRO, 1975).

26. McQueen, K. G., Hill, S. M. \& Foster, K. A. The nature and distribution of regolith carbonate accumulations in southeastern Australia and their potential as a sampling medium in geochemical exploration. J. Geochem. Explor. 67, 67-82 (1999)

27. Schmidt Mumm, A. \& Reith, F. Biomediation of calcrete at the gold anomaly of the Barns Prospect, Gawler Craton, South Australia. J. Geochem. Explor. 92, 13-33 (2007)

28. Beard, J. S. Plant Life of Western Australia (Kangaroo Press, 1990).

29. Verboom, W. H. \& Pate, J. S. Evidence of active biotic influences in pedogenetic processes. Case studies from semiarid ecosystems of south-west Western Australia. Plant. Soil. 289, 103-121 (2006).

30. Klappa, C. F. Rhizoliths in terrestrial carbonates: classification, recognition, genesis and significance. Sedimentology 27, 613-629 (1980).

31. Quade, J., Chivas, A. R. \& McCulloch, M. T. Strontium and carbon isotope tracers and the origins of soil carbonate in South Australia and Victoria. Palaeogeogr. Palaeoclimatol. Palaeoecol. 113, 103-117 (1995).

32. Cerling, T. E. The stable isotopic composition of modern soil carbonate and its relationship to climate. Earth Planet. Sci. Lett. 71, 229-240 (1984).

33. Lintern, M. J., Sheard, M. J. \& Chivas, A. R. The source of pedogenic carbonate associated with gold-calcrete anomalies in the western Gawler Craton, South Australia. Chem. Geol. 235, 299-324 (2006).

34. Edgecombe, D. Challenger gold deposit. Mines Energy Res. S. Aust. Quart. J. 4 , 8-11 (1997).

35. Paclawski, K. \& Wojnicki, M. Kinetics of the adsorption of gold (iii) chloride complex ions onto activated carbon. Arch. Metall. Mat. 54, 853-860 (2009).

36. Ong, H. L., Swanson, V. E. \& Bisque, R. E. Natural organic acids as agents of chemical weathering. U. S. Geol. Surv. Prof. Paper 700C, 130-137 (1969).

37. Reith, F. et al. A microbial pathway for the formation of gold-anomalous calcrete. Chem. Geol. 258, 315-326 (2009).

38. Borovicka, J. et al. Bioaccumulation of gold in macrofungi and ectomycorrhizae from the vicinity of the Mokrsko gold deposit, Czech Republic. Soil Biol. Biochem. 42, 83-91 (2010).

39. Cao, J. J. Migration mechanisms of gold nanoparticles explored in geogas of the Hetai ore district, southern China. Geochem. J. 45, E9-E13 (2011).

40. Cameron, E. M. From Chile to Nevada to the Athabasca basin: earthquakeinduced geochemical anomalies from near-field to far-field. Geochem: Explor. Env. Anal. 13, 41-51 (2013).

41. Muñoz, M. R. et al. Hydraulic lift in three shrub species from the Chilean coastal desert. J. Arid Environ. 72, 624-632 (2008).

42. Kerr, R. A. Is the world tottering on the precipice of peak gold? Science 335, 1038-1039 (2012).

43. Cohen, D. R. et al. Major advances in exploration geochemistry, 1998-2007. Geochem: Explor. Env. Anal. 10, 3-16 (2010).

44. Akob, D. M. \& Kusel, K. Where microorganisms meet rocks in the Earth's Critical Zone. Biogeosci. 8, 3531-3543 (2011).

45. Ryan, C. G. et al. The new Maia detector system: methods for high definition trace element imaging of natural material. AIP Conf. Proc. 1221, 9-17 (2010).

\section{Acknowledgements}

Industry members of Australian Mineral Industries Research Association Project P778 are thanked for their financial and logistical support. We thank Dr M. Verall for assisting with the SEM, and A. Vartesi and T. Naughton for figure construction. The manuscrip was improved with suggestions from CSIRO staff members Drs C. Butt and S. Barnes. The authors wish to acknowledge Drs M. de Jonge and D. Howard at the Australian Synchrotron for their assistance. Part of this research was undertaken on the XFM beamline at the Australian Synchrotron, Victoria, Australia.

\section{Authors contributions}

M.L. conceived, designed and implemented the research strategy for this work. He selected key field sites, collected samples, supervised sample preparation and analysis. $\mathrm{He}$ is the principal author. C.R. assisted in the collection and interpretation of the analytical data from the Australian Synchrotron specifically with respect to the identification of $\mathrm{Au}$ in the leaf samples. R.A. was the overall leader of the multi-client project (P778) under which some of the described research was undertaken. D.P. contributed his expertise at the Australian Synchrotron to ensure the instrumentation was running at optimal performance. He also assisted with the collection of images. 


\section{Additional information}

Supplementary Information accompanies this paper at http://www.nature.com/ naturecommunications

Competing financial interests: The authors declare no competing financial interests.

Reprints and permission information is available online at http://npg.nature.com/ reprintsandpermissions/
How to cite this article: Lintern, M. et al. Natural gold particles in Eucalyptus leaves and their relevance to exploration for buried gold deposits. Nat. Commun. 4:2614 doi: $10.1038 /$ ncomms3614 (2013).

(c) (1) (2) This work is licensed under a Creative Commons Attributioncc) NonCommercial-ShareAlike 3.0 Unported License. To view a copy of this license, visit http://creativecommons.org/licenses/by-nc-sa/3.0/ 


\title{
Publisher Correction: Natural gold particles in Eucalyptus leaves and their relevance to exploration for buried gold deposits
}

\author{
Melvyn Lintern, Ravi Anand, Chris Ryan \& David Paterson
}

Nature Communications 4:2614 doi: 10.1038/ncomms3614 (2013); Published online 22 Oct 2013; Updated 25 May 2018

The original HTML version of this Article had an incorrect article number of 2274; it should have been 2614 . This has now been corrected in the HTML; the PDF version of the Article was correct from the time of publication.

\footnotetext{
(c) (-) (-) Open Access This article is licensed under a Creative Commons Attribution-NonCommercial-ShareAlike 4.0 International License, which permits any noncommercial use, sharing, adaptation, distribution and reproduction in any medium or format, as long as you give appropriate credit to the original author(s) and the source, provide a link to the Creative Commons license, and indicate if changes were made. If you remix, transform, or build upon this article or a part thereof, you must distribute your contributions under the same license as the original. The images or other third party material in this article are included in the article's Creative Commons license, unless indicated otherwise in a credit line to the material. If material is not included in the article's Creative Commons license and your intended use is not permitted by statutory regulation or exceeds the permitted use, you will need to obtain permission directly from the copyright holder. To view a copy of this license, visit http://creativecommons.org/licenses/by-nc-sa/ $4.0 /$

(C) The Author(s) 2018
} 